\title{
Misfolding of the prion protein: linking biophysical and biological approaches
}

\author{
Sylvie NoINVILLE, Jean-François CHICH, Human REZAEI* \\ Institut National de la Recherche Agronomique, Virologie et Immunologie Moléculaires, \\ F-78352 Jouy-en-Josas, France
}

(Received 23 November 2007; accepted 03 June 2008)

\begin{abstract}
Prion diseases are a group of neurodegenerative diseases that can arise spontaneously, be inherited, or acquired by infection in mammals. The propensity of the prion protein to adopt different structures is a clue to its pathological and perhaps biological role too. While the normal monomeric PrP is well characterized, the misfolded conformations responsible for neurodegeneration remain elusive despite progress in this field. Both structural dynamics and physico-chemical approaches are thus fundamental for a better knowledge of the molecular basis of this pathology. Indeed, multiple misfolding pathways combined with extensive posttranslational modifications of $\operatorname{PrP}$ and probable interaction(s) with cofactors call for a combination of approaches. In this review, we outline the current physico-chemical knowledge explaining the conformational diversities of PrP in relation with postulated or putative cellular partners such as proteic or non-proteic ligands.
\end{abstract}

structure / membrane / oligomer / kinetics

Table of contents

1. Introduction .1

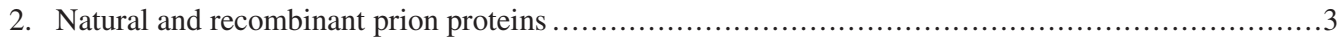

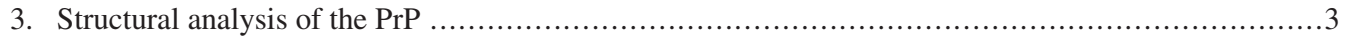

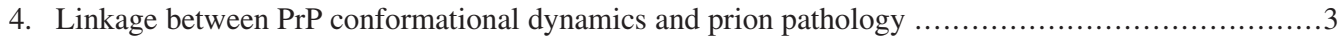

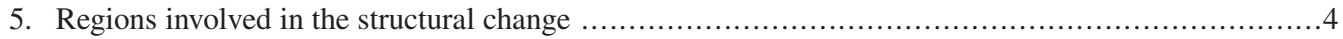

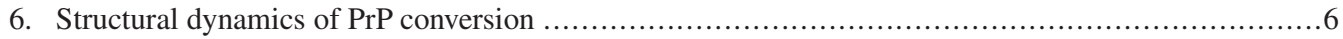

7. Conversion of prions is likely to occur at the membrane surface ......................................

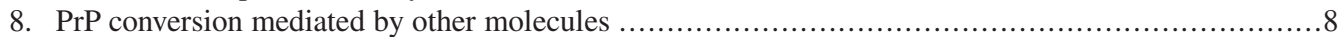

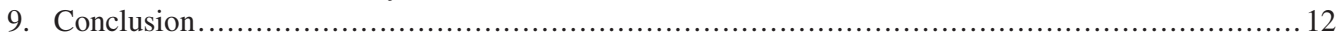

\section{INTRODUCTION}

Prion diseases, also known as transmissible spongiform encephalopathies (TSE) are a family of fatal neurodegenerative diseases affecting a number of mammalian species. TSE were first noted in sheep as scrapie, but also occur in cattle such as bovine spongiform encephalopathy (BSE) and in cervids such as chronic wasting disease (CWD). These diseases connected with the prion protein $(\mathrm{PrP})$

\footnotetext{
*Corresponding author: human.rezaei@jouy.inra.fr
}

also affect humans as for instance in kuru, Creutzfeldt-Jakob disease (CJD), GerstmannSträussler-Scheinker disease and fatal familial insomnia. Prion diseases may arise spontaneously, be inherited through mutations of the prion protein gene or be acquired through exposure to prion infected tissues. While usually rare, TSE can assume epidemic proportions under still unknown conditions.

The most unusual feature of TSE, which makes these diseases unique among the pathologies caused by protein misfolding, is 
the nature of the pathogenic agent in infectivity. It is now widely accepted, although not definitely proven, that the infective agent is the PrP itself according to the so-called "proteinonly hypothesis" [95]. Strong evidence indicates that the conversion of a normal soluble $\alpha$-helical monomeric protein into a $\beta$-sheetrich oligomeric structure and further fibrillar aggregation are the key events in the disease pathogenesis $[9,90]$. To distinguish between these two conformers of the same protein, the terms $\mathrm{PrP}^{\mathrm{C}}$ and $\mathrm{PrP}^{\mathrm{Sc}}$ are used to name respectively the endogenous non-pathogenic form and the disease-associated isoform. The misfolded $\mathrm{PrP}^{\mathrm{Sc}}$ is characterized by new biochemical properties such as protease resistance to proteinase $\mathrm{K}$ and forms insoluble aggregates observed as cerebral accumulations in different TSE [96]. The aberrant conformer $\mathrm{PrP}^{\mathrm{Sc}}$ is believed to act as a structural template, which induces conversion of other $\operatorname{PrP}^{\mathrm{C}}$ molecules to the pathological form [39]. Two prevalent hypotheses exist to explain the molecular mechanism of prion propagation, which has yet to be formally determined. The first one is the nucleation model which proposes that $\mathrm{PrP}^{\mathrm{Sc}}$ exists in equilibrium with $\operatorname{PrP}^{C}$ but can form oligomers acting as seeds for further polymerization [51]. The second one, known as the template-assisted model, proposes the formation of $\mathrm{PrP}^{\mathrm{C}}-\mathrm{PrP}^{\mathrm{Sc}}$ heterodimers which refold into a homodimer of $\mathrm{PrP}^{\mathrm{Sc}}$ [29]. The "protein only hypothesis" represents a new paradigm of molecular biology since it implies that proteins rather than viruses or nucleic acids may be infectious and carry heritable information. The ability of a protein to misfold into multiple self-propagating conformations would also be at the origin of prion inheritance in yeast and fungi prions as discussed and compared to mammal prions in recent reviews $[18,21]$.

Evidence to sustain these hypotheses in mammal models would be to determine infectious properties of aggregates produced in vitro from recombinant PrP. Legname et al. showed that injection of the recombinant mouse PrP in the form of amyloid-like fibrils is sufficient to generate disease in mice that express the endogenous protein [60]. Wild-type animals have been infected with aggregates produced in vitro from sonicated $\mathrm{PrP}^{\mathrm{C}}-\mathrm{PrP}^{\mathrm{Sc}}$ mixtures [13]. However, one can deplore the low level of infectivity of prion aggregates produced in vitro as already suggested by May et al. [73]. Silveira et al. attempted to determine the relationship between infectivity and converting activity with the size of various misfolded PrP-containing aggregates. Their analyses suggest that non-fibrillar particles, with masses equivalent to 14-28 PrP molecules, are the most efficient initiators of TSE disease [113]. Recently, amyloid fibrils prepared in vitro from full-length mouse recombinant prion protein (recPrP) were found to be as toxic to cells as soluble oligomeric intermediates [83]. Another comprehensive study showed that soluble $\beta$-rich oligomers of PrP were toxic to neuronal cells [56, 114]. But recPrP amyloid fibrils appeared to be more biologically active than the soluble $\beta$ rich oligomers since only the former induces synaptic impairments prior to neuronal death [84].

How prions damage cells and the precise nature of the neurotoxic agent in TSE are not fully understood. The synaptic loss is a prominent feature of prion diseases, which is observed at the early pre-clinical stages [25, $40,52]$ while neuronal death is typically observed at late clinical stages [16]. Other authors underlined the difficulties to establish the identification of the early molecular events associated with neuronal degeneration by a valuable biological model system [50, 84].

Because neurotoxicity and infectivity are so intimately related to a protein that may exist in at least two different conformational stable states and multiple meta stable oligomeric states, large interest has been paid over the last 15 years to establish the structure of PrP both in the native and in its various pathological forms and to understand the folding/misfolding pathway. Biophysical approaches (i.e. structural and protein physicalchemistry) could help for a better understanding of prion pathology and neurotoxicity at the molecular level since prion diseases originate from a protein folding problem and depend on its internal dynamics. 


\section{NATURAL AND RECOMBINANT PRION PROTEINS}

$\operatorname{PrP}$ is encoded by a single exon as a polypeptide chain of 250 to 260 amino acids depending on the species [86]. The posttranslational modification includes the cleavage of the $\mathrm{N}$-terminal signal sequence of 22 residues and the $\mathrm{C}$-terminal signal (23 residues) of the glycosylphosphatidylinositol (GPI) anchor. PrP also contains two sites of N-glycosylation [118]. When PrP is purified from natural sources, it was in some instance observed as a mixture of nonglycosylated, monoglycosylated, and biglycosylated species. Furthermore, the number of glycosylated variants (glycoforms) was estimated up to 50 different bi-, tri-, and tetra-antennary $\mathrm{N}$ linked oligosaccharides [103]. PrP inserts into the cellular plasma membrane through the GPI anchor attached to the C-terminus [116].

The structural characterization of extractive $\operatorname{PrP}^{\mathrm{C}}$ failed until now essentially due to its rarity and its poor purification yield. For these reasons, most of the biophysical investigations were performed on the recombinant PrP (recPrP) produced in Escherichia coli. This strategy leads to the purification of several milligrams of recPrP, which is neither glycosylated nor GPI anchored. Hornman et al. demonstrated the physico-chemical equivalence of recPrP and the extractive PrP through NMR, circular dichroism (CD) spectroscopies and thermal unfolding analysis [46].

\section{STRUCTURAL ANALYSIS OF THE PRP}

The first 3D structure of the PrP C-terminal domain was determined by nuclear magnetic resonance (NMR) in Wüthrich's laboratory; this comprehended the 121-231 globular domain of murine PrP [101]. Since then, several NMR structures from different mammalian species were resolved [62, 64]. All showed the same global fold (Fig. 1a), consisting in two short anti-parallel $\beta$-sheets (S1 and S2), a small $\alpha$-helix (H1) and two anti parallel helices $(\mathrm{H} 2$ and $\mathrm{H} 3)$ linked by the single disulfide bond.

More recently, high resolution crystallographic structures were established for sheep PrP variants $[32,43]$. They showed the same global fold as other mammalian species determined by NMR. However, these high resolution structures led to establish the molecular bases of the difference in the previously described energetic unfolding $[32,98]$. Furthermore, the use of an antibody (Fab-VRQ 14) in the crystallization trials helps to identify the segment of ovine PrP (OvPrP) with an unchanged secondary structure in the $\mathrm{PrP}^{\mathrm{C}}$-to$\mathrm{PrP}^{\mathrm{Sc}}$ conversion. Indeed the Fab of VRQ 14 antibody recognized the $\mathrm{C}$-terminal end of helix $\mathrm{H} 2$ and the N-terminal part of the $\mathrm{H} 2-\mathrm{H} 3$ loop (Fig. 1b). ELISA titrations with normal or infected brain homogenates from the mouse, hamster, and macaque indicate that the VRQ 14 Fab epitope is also found in these species and is conserved in both normal and pathological isoforms of their prion proteins.

The structural characterization of the $\mathrm{N}$ terminal as well as by NMR or CD spectroscopy reveals that this region is unfolded in solution [29]. However, four repetitions of eight amino acids called the octapeptide domain present a high affinity for $\mathrm{Cu}^{2+}$ ions. The interaction of this octapeptide and $\mathrm{Cu}^{2+}$ leads to a partial structuration of this region [1].

\section{LINKAGE BETWEEN PrP CONFORMATIONAL DYNAMICS AND PRION PATHOLOGY}

The conformational diversity of PrP was proposed to be at the origin of all prion pathology [126]. In practice, PrP can adopt several structures through multiple folding pathways leading to the formation of some conformers associated to the apparition of pathological symptoms [4]. Several studies converge in supporting the diversity of pathological conformers: the first one and, probably, the most evident with respect to physico-chemical considerations, is the species barrier [93], and the second one is the anatomopathological diversity linked to the strain phenomena [23]. The species barrier resulting from PrP sequence variation implicates that the infectious conformer can harbor diverse conformations modulated by its primary structure [93]. This type of modulation was also reported in a given species and called "the polymorphism barriers" [53, 74]. The best example of this 


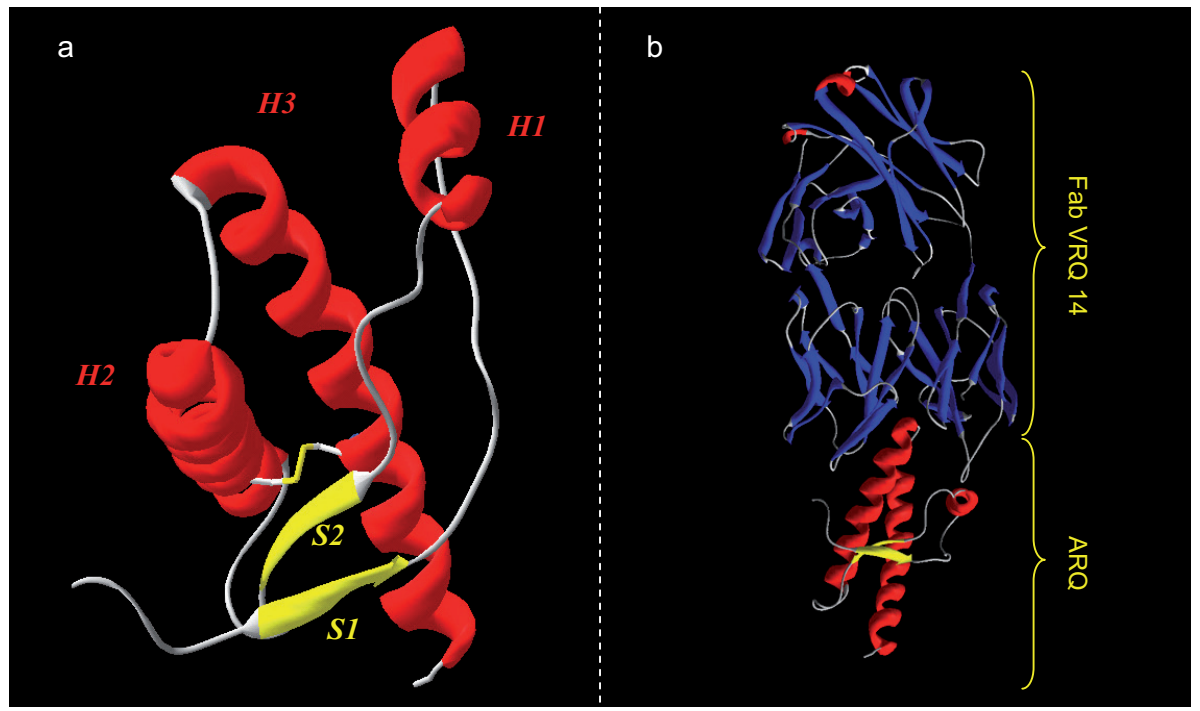

Figure 1. Structural characterization of the recombinant PrP. (a) The first characterization of PrP in 1996 by Riek et al. [101] reveals two short $\beta$-strands (S1 and S2), a small $\alpha$-helix and two anti-parallel $\alpha$-helices linked by a disulfide bond. (b) Recently, crystallographic approaches give high-resolution 3D structures of different mammalian prion proteins. Here a crystallographic structure obtained by the co-crystallization of VRQ 14 Fab with ARQ sheep variant. (A color version of this figure is available online at www.vetres.org.)

modulation was found in sheep species for which just a single mutation (Q171R) can protect against the sheep scrapie agent [10].

Several approaches were actually adopted to investigate the PrP conformational diversities. The use of a low chaotropic concentration ( $\sim 2 \mathrm{M}$ urea or guanidium chloride) is one of the strategies which can lead to the formation of amyloid fibrils [4, 76, 122]. Recently the Baskakov's group showed that fragmentation of amyloid fibrils under different physicochemical constraints such as temperature or shaking rate leads to the formation of fibrillar fragments whose size is correlated to the conformationional stability of prion fibrils [68, 120].

Comparing the PrP 3D structures leads to extract information about its folding dynamics and its structural diversity. The unfolding studies of recombinant PrP induced by temperature [99], pressure [69] or by urea or guanidine hydrochloride $[8,76,122]$ revealed that the monomeric and $\alpha$-helical conformer can be refolded into several oligomeric conformers presenting a high content of $\beta$-sheet.
According to calorimetric studies it appears that the PrP unfolding leads to the formation of an unidentified transient intermediate below $\mathrm{pH} 4.5$ and over $\mathrm{pH} 6.0$ giving rise to beta oligomers and/or amyloid fibrils (Fig. 2) [98]. Clearly, the protonation states of some PrP residues can particularly affect the folding pathway of the protein.

\section{REGIONS INVOLVED IN THE STRUCTURAL CHANGE}

As cited previously, the prion pathology belongs to diseases due to protein misfolding families. The misfolding term means that the protein can exist at least in two structures. Taking into account the fundamental biophysical principles of a macromolecule's behavior, the passage of one conformer to another can only occur through at least a partial unfolding process. Another important point, which remains obscure, is the region of $\operatorname{PrP}$ that is involved in the structural conversion. This lack in information is mostly due to the absence of the $\mathrm{PrP}^{\mathrm{Sc}}$ high resolution $3 \mathrm{D}$ structure. 


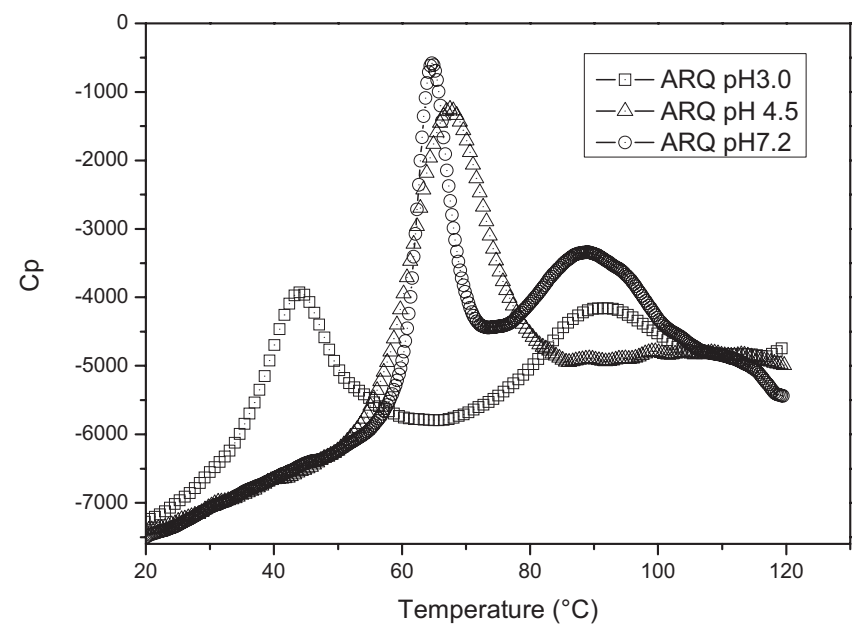

Figure 2. The diversity of PrP folding pathway explored by differential scanning calorimetry. The calorimetric thermograms of the unfolding process at different $\mathrm{pH}$ reveal different unfolding pathways. At a $\mathrm{pH}$ below 4.5 and over $\mathrm{pH}$ 6.0, unfolding occurs with the existence of an intermediate, characterized as an oligomeric state of $\operatorname{PrP}[98]$.

Proteolysis fingerprinting performed on extractive $\mathrm{PrP}^{\mathrm{Sc}}$ reveals that the N-terminal region is completely accessible to proteases [89]. Furthermore, transgenic mice whose Nterminal PrP domain was deleted, were able to replicate the infectious agent $[36,102]$. All these observations indicate that the $\mathrm{N}$-terminal part of PrP plays a minor role in the conversion process. However, in transgenic mice the deletion of this region affects the anatomopathological distribution of the lesions as well as the incubation period.

In earlier 2000, the molecular dynamics tried to determine the PrP region presenting a dual structure. The first target was helix H1, which contains about 10 amino acids. Morrissey and Shakhnovich [78] first predicted that $\mathrm{H} 1$ might be involved in the seeding of prion aggregates, noting that $\mathrm{H} 1$ is an unusually hydrophilic $\alpha$-helix with few contacts with the remainder of the molecule, whereas $\mathrm{H} 2$ and $\mathrm{H} 3$ are hydrophobic and linked by a disulfide bond. The particular interest for the H1 helix was mostly due to the nucleation theory [88], which predicts that $\operatorname{PrP}^{\mathrm{C}}$ to $\mathrm{PrP}^{\mathrm{Sc}}$ conversion can be initiated by the propagation of a $\beta$-structure starting from the two short $\operatorname{PrP}^{\mathrm{C}}$ $\beta$-strands (S1 and S2). According to this the- ory, $\mathrm{H} 1$ constitutes the junction between these two $\beta$-strands (Fig. 3) and thus its conformation and stability may play an important role in the conversion kinetics. Other experimental data support the evidence that the $\mathrm{H} 1$ helix is a possible site of association of $\mathrm{PrP}^{\mathrm{Sc}}$ with $\mathrm{PrP}^{\mathrm{C}}$ during formation of the $\mathrm{PrP}^{\mathrm{Sc}}-\mathrm{PrP}^{\mathrm{C}}$ complex. For instance, an antibody directed against $\mathrm{H} 1$ cured prion infections in two separate cell lines chronically infected with $\operatorname{PrP}^{S c}[34,45,92]$. It is noteworthy that antibodies obtained against other regions of PrP have also been reported to inhibit the replication of the infectivity [35, 85], suggesting that $\operatorname{PrP}^{\mathrm{Sc}}$ replication may involve different regions of the prion protein.

More recently and in parallel to the particular interest focused on $\mathrm{H} 1$, the $\mathrm{H} 2$ and $\mathrm{H} 3$ helices solicited a regain of interest. Dima and Thirumalai first showed by molecular dynamics that some segments of $\mathrm{H} 2$ and $\mathrm{H} 3$ presented significant instability [28]. Then they proposed that some structural changes in these two helices might be at the origin of transition of $\operatorname{PrP}^{\mathrm{C}}$ to $\mathrm{PrP}^{\mathrm{Sc}}$ although a disulfide bond linked these two helices covalently. Furthermore, $\mathrm{H} 2$ and $\mathrm{H} 3$ helices may play an important role in the conversion process as proposed from hydrogen/deuterium exchange 


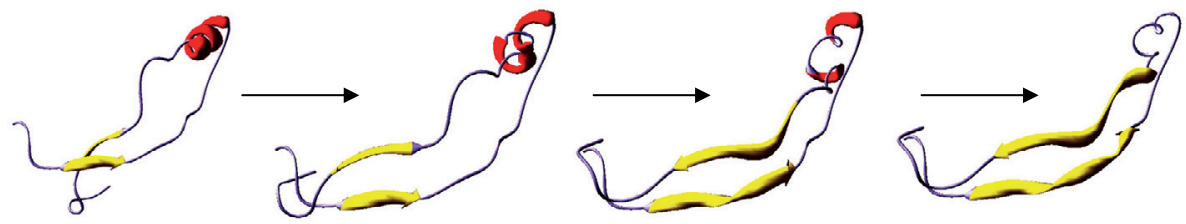

Figure 3. The structural basis of $\mathrm{PrP}^{\mathrm{C}}$-to- $\mathrm{PrP}^{\mathrm{Sc}}$ conversion. The two $\beta$-strands $\mathrm{S} 1$ and $\mathrm{S} 2$ are proposed to play the role of a "seed" for elongation during $\mathrm{H} 1$ unfolding. This hypothesis has been exploited to design inhibitor molecules (called "beta breakers") for $\mathrm{PrP}^{\mathrm{C}}$-to- $\mathrm{PrP}^{\mathrm{Sc}}$ conversion. (A color version of this figure is available online at www.vetres.org.)

experiments and from the hydration properties of the unfolded state of PrP investigated by molecular dynamics [26, 63].

\section{STRUCTURAL DYNAMICS OF PrP CONVERSION}

Several biochemical and physico-chemical approaches well described the structural difference between $\operatorname{PrP}^{\mathrm{C}}$ and $\mathrm{PrP}^{\mathrm{Sc}}$. However, an important question remains concerning the early structural events during $\mathrm{PrP}^{\mathrm{C}}$-to- $\mathrm{PrP}^{\mathrm{Sc}}$ conversion.

Recently we tried to address this question by two approaches: the first one was to establish a kinetic scheme describing the recombinant PrP oligomerization at acidic $\mathrm{pH}$, and the second one was to introduce some physical constraints in defined PrP regions so as to study the impact on the oligomerization pattern (Fig. 4a) [33]. The kinetic investigation showed that PrP can generate different types of oligomers according to a parallel oligomerization pathway (Fig. 4b). Only one of these oligomers was identified to be amyloidogenic. By locking sub-domains of PrP with disulfide bonds, we showed that the S1-H1-S2 domain must physically separate from the $\mathrm{H} 2-\mathrm{H} 3$ domain prior to oligomerization. This opening mechanism illustrated in Figure $4 \mathrm{c}$ implies a conformational change in the $\mathrm{S} 2-\mathrm{H} 2$ hingeloop corresponding to residues 168-173. Altogether kinetic and structural data reported by Eghiaian et al. are consistent with observations related to the $\mathrm{PrP}^{\mathrm{C}} / \mathrm{PrP}^{\mathrm{Sc}}$ conversion in vivo [33]. The conformation of the $\mathrm{S} 2-\mathrm{H} 2$ loop seems to play an important role in $\mathrm{PrP}^{\mathrm{C}} / \mathrm{PrP}^{\mathrm{Sc}}$ conversion. (i) Protein $\mathrm{X}$ was putatively proposed to target the $\mathrm{S} 2-\mathrm{H} 2$ loop and to promote the opening of the molecule like a lever [54]; (ii) in sheep, mutation Q171R located in the S2-H2 loop confers a resistance phenotype to sheep scrapie [49]; (iii) the conformation of this loop was proposed as the basis of TSE susceptibility differences in domestic animals [41]. Since the separation of H1-S2 from the rest of the protein is a prerequisite unfolding event for oligomerization, all mutations affecting the $\mathrm{H} 1-\mathrm{S} 2$ expansion from the $\mathrm{H} 2-\mathrm{H} 3$ bundle may be involved in the $\mathrm{PrP}^{\mathrm{C}} / \mathrm{PrP}^{\mathrm{Sc}}$ conversion as for the human $\mathrm{Q} 217 \mathrm{R}$ mutation.

\section{CONVERSION OF PRIONS IS LIKELY TO OCCUR AT THE MEMBRANE SURFACE}

Under normal physiological conditions, cellular PrP is incorporated in the outer layer of the plasma membrane via a glycosylphosphatidylinositol (GPI) anchor. Like other GPIanchored proteins, $\mathrm{PrP}^{\mathrm{C}}$ is localized in membrane microdomains enriched in cholesterol and sphingomyelin so-called rafts. Depletion of cholesterol from cellular membranes prevents $\mathrm{PrP}^{\mathrm{Sc}}$ formation [5, 12, 123]. In contrast, depletion of sphingolipid increases the $\mathrm{PrP}^{\mathrm{Sc}}$ formation in prion-infected neuroblastoma cells [82]. $\mathrm{PrP}^{\mathrm{C}}$ is easily cleaved and released from the cell surface after digestion with phosphatidylinositolphospholipase $\mathrm{C}$ (PI-PLC), whereas $\mathrm{PrP}^{\mathrm{Sc}}$ is resistant to release [106, 117]. The effect of GPI anchor on the conversion of PrP expressed in fibroblasts has been tested [3]. Both GPI-anchored and GPI-deficient $\mathrm{PrP}^{\mathrm{C}}$ are associated into raft domains. But the GPI-anchored PrP could not be converted into $\mathrm{PrP}^{\mathrm{Sc}}$ without the action of PI-PLC or addition of a membranefusion agent, while the GPI-deficient PrP 
a

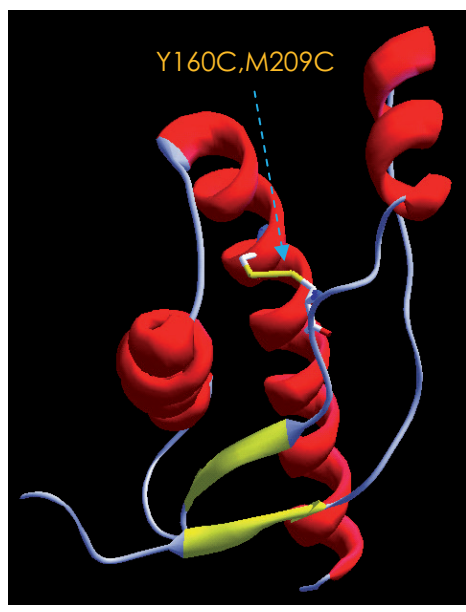

b

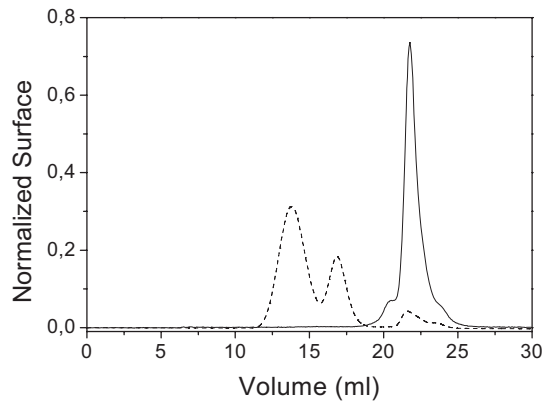

C

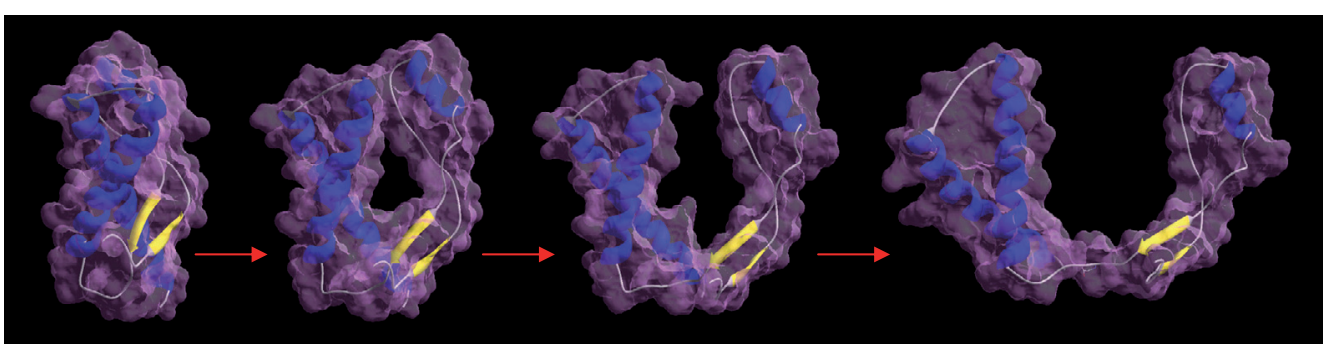

Figure 4. An artificial disulfide bond was used to explore the structural basis of the recombinant PrP conversion (a). The covalent linkage of the S1-H1-S2 domain to the H2-H3 domain through an artificial S-S bond (Y160C, M209C) leads to the complete inhibition of PrP oligomerization as shown by Size Exclusion Chromatograms (b). A diagram showing that the expanding of the S1-H1-S2 domain from the rest of the protein is required prior to oligomerization (c). (A color version of this figure is available online at www.vetres.org.)

undergoes conversion without PI-PLC or fusogenic agent. These findings suggest that lipid-PrP interaction could form anchorless intermediates playing a role in the conversion of $\mathrm{PrP}^{\mathrm{C}}$ into $\mathrm{PrP}^{\mathrm{Sc}}$ provided the interacting $\mathrm{PrP}^{\mathrm{C}}$ is still membrane-anchored via the GPI moeity.

Although the majority of $\mathrm{PrP}^{\mathrm{Sc}}$ generated in infected animals contains a GPI anchor, soluble forms of PrP released from the cell surface are GPI deficient and observed in murine neuroblastoma or in mice cell culture $[9,14$, 15] or directly in mice brains [91]. Besides in scrapie-infected cells the absence of the GPI anchor reduces conversion [102], which suggests that conversion involves membranebound GPI-anchored PrP. The role of the anchor-deficient form of PrP in regards with susceptibility to TSE infection in vivo is still under debate. In transgenic mice, combined expression of GPI-anchored and GPI-deficient PrP increases clinical scrapie whereas expression of solely GPI-deficient PrP produces infectious particles without clinical signs [19]. But it cannot be excluded that soluble intermediates of PrP could play a role in the conversion process $[19,59,60]$.

Only a few in vitro biophysical studies have been dedicated to lipid-prion protein interaction, generally employing a recombinant 
full-length or N-truncated polypeptide of $\operatorname{PrP}^{\mathrm{C}}$. Although these two recombinant forms are neither glycosilated nor GPI anchored, they undergo a structural transition from an $\alpha$-helical state to a $\beta$-sheeted structure that mimick on a conformational point of view the $\mathrm{PrP}^{\mathrm{C}}$ to $\mathrm{PrP}^{\mathrm{Sc}}$ conversion. The interaction of $\alpha$-helical recombinant PrP with model lipid membranes has been characterized [75, 107] as well as those of the $\beta$-sheeted form $[24,55]$.

The native and $\beta$-sheeted forms have different binding affinities to lipid membranes. Both native and converted forms bind to negatively charged lipid membranes in a $\mathrm{pH}$-dependent manner [24, 55, 75, 107]. No binding occurs when prion protein interacts with pure zwitterionic phosphatidylcholine (PC) lipids. But both native and $\beta$-sheeted conformers bind to model raft membranes constituted of PC, cholesterol and sphingomyelin [55, 107]. The native conformer interacts with rafts only at $\mathrm{pH} 7$, while the $\beta$-sheeted form binds strongly at both neutral and acidic $\mathrm{pH}$ [24].

The lipid membrane-prion interaction results either in a conformational change of the protein and/or in a destabilization of the lipid membrane, depending on $\mathrm{pH}$, membrane composition and initial conformation of the $\operatorname{PrP}$ species. Both native and $\beta$-sheeted forms of the $\mathrm{N}$-truncated PrP gain in $\beta$-structure upon binding to negatively charged phosphatidylglycerol (PG) vesicles leading to total release of the lipid vesicles [55, 107]. These interactions with negatively charged vesicles result in PrP aggregation whatever the initial conformation of the PrP in any $\mathrm{pH}$ studied. With raft model membranes, the native helical conformer of $\mathrm{N}$-truncated $\mathrm{PrP}$ is more folded in helical structure and does not lead to $\operatorname{PrP}$ aggregation while $\beta$-conformer upon binding is unfolded and leads to fibrillization of PrP. However, full length PrP bearing a synthetic GPI anchor in the $\alpha$-helical state remains structurally rather unchanged when interacting with raft vesicles [30], suggesting that raft domains could protect the cellular helical conformer from $\beta$-conversion (Fig. 5). However, endocytosis studies have shown that in vivo $\operatorname{PrP}^{\mathrm{C}}$ leaves rafts and transits outside rafts via clathrin coated pits before being re- cycled back to the plasma membrane [121]. During transit outside rafts, PrP could bind to negatively charged lipids, leading to a precursor in $\beta$-rich structure prone to aggregation. The higher affinity of the $\beta$-conformer towards raft microdomains enables to speculate the accumulation of these $\beta$-rich intermediates in the vicinity of $\operatorname{PrP}^{\mathrm{C}}$ embedded in the lipid membrane. Thus, both $\mathrm{PrP}^{\mathrm{C}}$ and $\mathrm{PrP}^{\mathrm{Sc}}$ should be localized in raft domains to ensure the prion propagation in vivo and to alter the normal trafficking of $\mathrm{PrP}^{\mathrm{C}}$ in neuronal cells. In infected cells, $\operatorname{PrP}^{\mathrm{C}}$ would be internalized with bound pathological PrP, leading to further $\beta$-conversion. The localization of the $\beta$-conversion could be either at the membrane or in endosomes/lysosomes. As hypothesized in Figure 5, the transconformed PrP poisons several other cell compartments, affecting cellular machinery (especially protein synthesis and degradation), and, due to its proteaseresistance, accumulates in aggregates.

\section{PrP CONVERSION MEDIATED BY OTHER MOLECULES}

In order to unravel the normal role of PrP or to find cofactors (e.g. protein $\mathrm{X}$ according to Telling et al.) involved in transconformation from $\mathrm{PrP}^{\mathrm{C}}$ to $\mathrm{PrP}^{\mathrm{Sc}}$, several molecules interacting with PrP were identified [125]. These molecules are listed in Table I and can be subdivided into two groups:

(1) Non-proteic ligands. PrP can bind to nucleic acids. Co-precipitations of PrP and DNA were performed. PrP can also interact with membrane lipids and can be converted into $\beta$-sheeted structure, or can keep its native conformation when inserted in rafts. Peptides derived from PrP induce liposome fusion (118135) [17] or can form ionic channels (106-126) [57]. These peptides induce apoptosis of cells by interacting with biological membranes. It was shown that heparan sulfate can bind $\operatorname{PrP}$ [38, 111]. These ligands are components of the extracellular matrix and were shown to be of great importance for neuron growth, a function postulated for the prion protein. Interestingly, heparan sulfate mimetics are also promising drugs for prion disease curing. PrP was shown to bind metals selectively and 


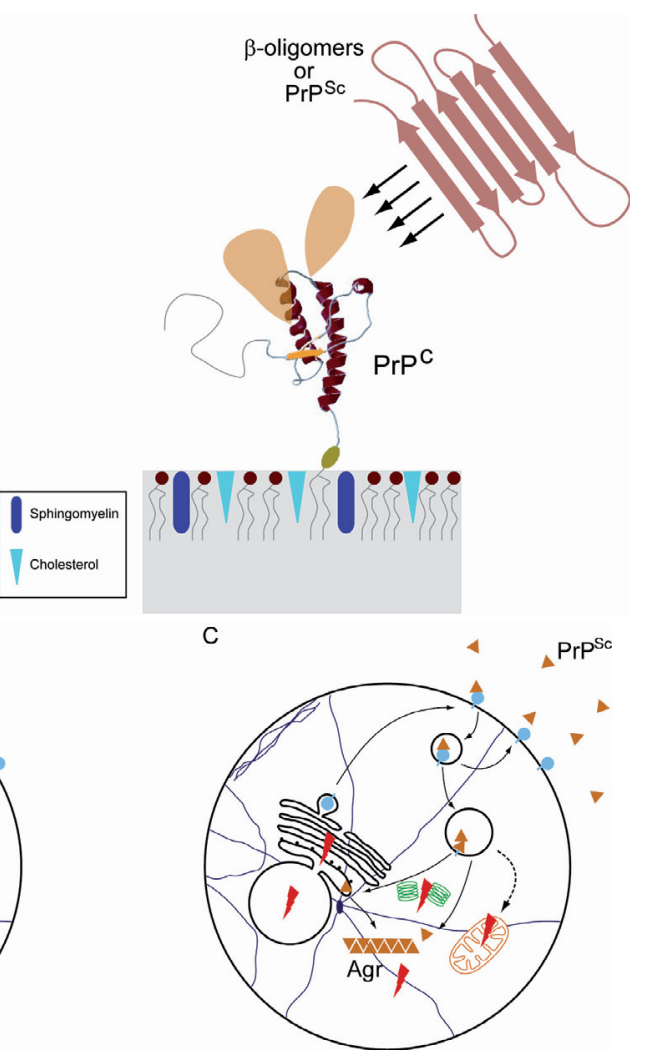

Figure 5. Model for the cellular toxicity of oligomeric $\operatorname{PrP}$ species: (A) The normal $\operatorname{PrP}^{\mathrm{C}}$ isoform is embedded in rafts via the GPI anchor. $\beta$-rich intermediates, either soluble oligomers or $\mathrm{PrP}^{\mathrm{Sc}}$ itself, have high affinities towards raft microdomains leading to their accumulation in the vicinity of $\operatorname{PrP}^{\mathrm{C}}$. The oligomeric species could interact with the normal protein leading to structural conversion and/or change in signal properties. (B) In non-infected cells, $\mathrm{PrP}^{\mathrm{C}}$ trafficking is normal, as described in the literature and text. In infected cells, $\mathrm{PrP}^{\mathrm{C}}$ is internalized with bound $\mathrm{PrP}^{\mathrm{Sc}}$. Transconversion could occur either at the membrane or in endosomes/lysosomes. (C) In infected cells, due to its resistance to proteolytic digestion, $\mathrm{PrP}^{\mathrm{Sc}}$ accumulates more and more and "poisons" several cell compartments [20, 65, 66, 114]. Abbreviations and symbols used are the following: Agr ( $\mathrm{PrP}^{\mathrm{Sc}}$ aggregates), Cy (cytoskeleton), End (endosome), N (nucleus), Lys (lysosome), Ps (proteasome), Mt (mitochondrion), ER (endoplasmic reticulum), G (Golgi apparatus). Arrows indicate the cellular compartments/functions affected by infection. (A color version of this figure is available online at www.vetres.org.)

especially copper. A function in cell redox regulation was proposed.

(2) Proteic ligands involved in various cellular functions. Computational data ${ }^{1}$ indicate a limited number of interactions for PrP while the literature shows more PrP interactors. Two chaperones were proposed to intervene in the

${ }^{1}$ String, EMBL: http://string.embl.de [consulted 22/05/2008]. $\alpha / \beta$ conversion of PrP, the cytoplasmic Hsp73 and curiously, the bacterial GroEL, while the important Hsp70 chaperone had no role in the PrP conversion [112]. Peptides corresponding to internal sequences of $\operatorname{PrP}$ (109-122 and 109-141) were shown to interact in vitro with apolipoprotein E [6]. Receptor proteins playing a role in signal transduction were found to interact directly such as laminin receptor [128] or indirectly like kinase Fyn [79], with internal 
Table I. Non-exhaustive summary of PrP or PrP-derived peptide interactions with various ligands and proposed roles for these interactions.

\begin{tabular}{|c|c|c|c|}
\hline $\begin{array}{l}\text { Ligand } \\
\text { nat }\end{array}$ & Identification method & Possible role & References \\
\hline \multicolumn{4}{|l|}{ Non-proteic ligands } \\
\hline Heparan sulfate & $\begin{array}{l}\text { Synthetic peptides, CD } \\
\text { Cultured cells }\end{array}$ & $\begin{array}{l}\text { Component of amyloid structures } \\
\text { Competition for copper binding }\end{array}$ & {$[38,111]$} \\
\hline Gangliosides & $\begin{array}{l}\text { Neurons and lymphocyte } \\
\text { labeling }\end{array}$ & $\begin{array}{l}\mathrm{PrP}^{\mathrm{C}}-\mathrm{GM} 3 \text { complex involved in } \mathrm{T} \text { cell } \\
\text { activation and other membrane } \\
\text { functions }\end{array}$ & [72] \\
\hline Lectin CBP70 & $\begin{array}{l}\text { Immunofluorescence, flow } \\
\text { cytometry, Western blots }\end{array}$ & Helps conversion of $\operatorname{PrP}^{C}$ into $\mathrm{PrP}^{\mathrm{Sc}}$ & [104] \\
\hline Nucleic acids & $\begin{array}{l}\text { Co-aggregation ADN-PrP. } \\
\text { Binding of ARN aptamers }\end{array}$ & $\begin{array}{l}\text { Could give a role for anucleic acid in } \\
\text { infection. Useful for a diagnostic using } \\
\text { ARN? }\end{array}$ & {$[80,81,128]$} \\
\hline Membrane lipids & Tryptophane fluorescence & $\begin{array}{l}\text { Insertion in membrane, conformation } \\
\text { change into structure and leakage of } \\
\text { vesicle content. In rafts, conformation } \\
\text { into structure. A role in } \\
\text { transconformation of PrP }\end{array}$ & [107] \\
\hline Membrane lipids & $\begin{array}{l}\text { PrP (118-135) destabilizes } \\
\text { membranes }\end{array}$ & $\begin{array}{l}\text { Induces apoptosis of rat cortical } \\
\text { neurons }\end{array}$ & [94] \\
\hline $\begin{array}{l}\text { POPG }>\text { DPPC }> \\
\text { rafts }\end{array}$ & BIAcore & $\begin{array}{l}\text { The strength of the association of } \operatorname{PrP} \\
\text { with lipid membranes depends on the } \\
\text { protein conformation and pH }\end{array}$ & [24] \\
\hline Copper & $\begin{array}{l}\text { Circular dichroism and } \\
\text { tryptophane fluorescence }\end{array}$ & $\begin{array}{l}\text { Copper binds on octarepeat. A role in } \\
\text { transport of cellular } \mathrm{Cu} \text {, a SOD fonction }\end{array}$ & {$[47,119]$} \\
\hline
\end{tabular}

Proteins

Apolipoprotein E Thioflavine fluorescence

Interaction with $\operatorname{PrP}(109-122)$ and

(109-141). A role in amyloidogenicity?

Pli45, Pli110 Ligand blot

Pli3, Pli4, Pli5, Pli6, PrP-Alkaline phosphatase

Pli7, Pli8

screening

$37 \mathrm{kDa} / 67 \mathrm{kDa}$

laminin receptor

Double hybrid in yeast.

Cell binding

Laminin

Binding on PC12 cells, in presence of NGF

$66 \mathrm{kDa}$ protein

Complementary

hydropathy, binding competition

$\mathrm{Bcl} 2$

Double hybrid in yeast
Receptor to PrP before internalization and signal transduction

Bcl2 protects cells from apoptosis.

Binding with PrP inhibits the protective role
$[48,100]$

$[71,70]$

$[58,97]$

$[37,67]$ 
Table II. Continued.

\begin{tabular}{|c|c|c|c|}
\hline Ligand & Identification method & Possible role & References \\
\hline \multicolumn{4}{|l|}{ Proteins (continued) } \\
\hline N-CAM & $\begin{array}{l}\text { Cross-linking in situ, mass } \\
\text { spectrometry, KO mice }\end{array}$ & & [109] \\
\hline and tubulin & Cell cultures & & [11] \\
\hline Synapsin Ib & $\begin{array}{l}\text { Double hybrid in yeast and } \\
\text { co-immunoprecipitation }\end{array}$ & $\begin{array}{l}\text { Presynaptic vesicle control. A role in } \\
\text { signal transduction? }\end{array}$ & [115] \\
\hline Grb2 & $\begin{array}{l}\text { Double hybrid in yeast and } \\
\text { co-immunoprécipitation }\end{array}$ & $\begin{array}{l}\text { Synaptic vesicle control. A role in } \\
\text { signal transduction? }\end{array}$ & [115] \\
\hline Pint1 & $\begin{array}{l}\text { Double hybrid in yeast and } \\
\text { co-immunoprécipitation }\end{array}$ & & [115] \\
\hline Fyn & $\begin{array}{l}\text { Cross-linking with } \\
\text { antibodies }\end{array}$ & Signal transduction via a PrP receptor & [79] \\
\hline $\mathrm{P}$ & $\begin{array}{l}\text { PrP KO mice, PrP with N- } \\
\text { ter deletions }\end{array}$ & Hypothetical, role similar to $\operatorname{PrP}$ & [110] \\
\hline Calcineurin B & BIAcore & Ser/Thr phosphatase & [77] \\
\hline "kringle" domain & $\begin{array}{l}\text { Phage display cDNA } \\
\text { expression library }(\mathrm{ScN} 2 \mathrm{a})\end{array}$ & & {$[105]$} \\
\hline STI1 & In vivo, antibodies & $\begin{array}{l}\text { Signal transduction activation; } \\
\text { neuritogenesis and neuroprotection }\end{array}$ & [61] \\
\hline vitronectin & co localisation in vivo & Axonal growth & [44] \\
\hline caveolin-1 & in vitro interaction & $\begin{array}{l}\text { Aggregation PrP-cav1 induces signaling } \\
\text { cascade }\end{array}$ & [127] \\
\hline $\operatorname{Rdj} 2$ & & chaperonin & [7] \\
\hline TREK-1 2P domain & $\begin{array}{l}\text { Double hybrid in bacteria, } \\
\text { transfected cells }\end{array}$ & $\begin{array}{l}\text { Interaction modulates } \\
\text { electrophysiological-dependent cellular } \\
\text { response }\end{array}$ & [2] \\
\hline
\end{tabular}

Chaperonins

\begin{tabular}{|c|c|c|c|}
\hline Hsp70 & $\begin{array}{l}\text { Thermal shock on NT-2, } \\
\text { simultaneous increase of } \\
\text { Hsp70 and PrP ARNm. } \\
\text { Interaction with HSE1 et } \\
\text { HSE2 }\end{array}$ & $\begin{array}{l}\text { Folding of translocated proteins. No } \\
\text { effect on PrP conversion }\end{array}$ & [112] \\
\hline Hsp60 & Stabilization of folding & Postulated "Protein X" & [31] \\
\hline Hsp73 & $\begin{array}{l}\text { Heat shock in N2a and } \\
\text { ScN2a cells }\end{array}$ & $\begin{array}{l}\text { A link between expression of Hsp73 } \\
\text { and PrPSc accumulation }\end{array}$ & [124] \\
\hline Hsp104 & Circular dichroism & $\begin{array}{l}\text { Interaction of PrP with } \mathrm{Hsp} 104 \text { changes } \\
\text { the structure of } \mathrm{Hsp} 104 \text { and inhibits its } \\
\text { ATPase activity }\end{array}$ & [108] \\
\hline GroEL & $\begin{array}{l}\text { Double hybrid and peptide } \\
\text { mapping. In vitro, cell-free } \\
\text { conversion }\end{array}$ & $\begin{array}{l}\text { Hsp } 104 \text { and GroEL affects in vitro, the } \\
\text { conversion of the hamster } \operatorname{PrPC}^{\mathrm{C}} \text { into } \\
\text { PrPSc }\end{array}$ & {$[27,31]$} \\
\hline
\end{tabular}


cell machinery. $\alpha$ - and $\beta$-tubulin and N-CAM, cytoskeleton or close to cytoskeleton proteins were also found to interact with PrP.

Proteins implicated in neuronal functions were described to interact with PrP; synapsin $\mathrm{Ib}$ and Grb2, both proteins involved in presynaptic vesicle control, co-precipitate with PrP in a microsome fraction, calcineurin $\mathrm{B}$, a ser/thr phosphatase located in synaptosomes interact with PrP. These proteins may also play a role in signal transduction.

Some intracellular proteins like Bcl-2 having an anti-apoptotic function and several other proteins without defined functions such as Pli, [129] and Pint1 [115] interact with PrP. Plasminogen, found in intercellular medium and in blood, binds $\operatorname{PrP}^{\mathrm{Sc}}$ but not $\operatorname{PrP}^{\mathrm{C}}$ [67].

The recent studies of PrP interactions seem to point towards interactions of PrP with extracellular proteins such as vitronectin [44] or glycosaminoglycans (heparin) and with proteins located in rafts like caveolin-1 [127] to transduct signals via the Fyn pathway. These signals could induce neuroprotection or neuritogenesis [61] or even short term and longterm memory [22].

It seems difficult to conclude definitely on the specificity of most of the interactions detected and their role in PrP transconformation due to the conformation of the protein used for assays (with or without non-structured Ntermini, glycosyl moiety or GPI-anchor) and the kind of assay performed (co-precipitation, yeast double hybrid etc.).

\section{CONCLUSION}

Like other amyloidopathies, prion disease is characterized by conformational changes leading to the apparition of new physico-chemical properties. Although, the structural characterization of $\mathrm{PrP}^{\mathrm{C}}$ through its recombinant form has been well documented, $\mathrm{PrP}^{\mathrm{Sc}}$ suffers from the absence of structure and biochemical characterization. Thus poor information is available concerning the molecular bases of $\mathrm{PrP}^{\mathrm{C}}$ to- $\mathrm{PrP}^{\mathrm{Sc}}$ conversion. One of the examples of this lack is the relation between PrP folding dynamics, structural diversities and strain phenomenon. The link between these biophysical and biological aspects remains to be exper- imentally established although multiple PrP folding pathways offer a rationale to correlate structural dynamics and physical hypothesis about the origin of prion strains. So far, the strain phenomenon is only attributed to biochemical and anatomopathology diversity.

Last, biological and cellular approaches show the complexity of establishing a biologically significant PrP interaction network. Currently, the relation between conformational change and cell death remains obscure. For example how can a cell in a cell culture model replicate the infectious agent massively without an effective toxicity.

Finally, it must be noted that a single approach cannot give a definitive answer on the mechanisms of prion infection and toxicity and it can be emphasized that multiple coordinated approaches should be helpful in unravelling the prion complexity.

\section{REFERENCES}

[1] Aronoff-Spencer E., Burns C.S., Avdievich N.I., Gerfen G.J., Peisach J., Antholine W.E., et al., Identification of the $\mathrm{Cu}^{2+}$ binding sites in the Nterminal domain of the prion protein by EPR and CD spectroscopy, Biochemistry (2000) 39:13760-13771.

[2] Azzalin A., Ferrara V., Arias A., Cerri S., Avella D., Pisu M.B., et al., Interaction between the cellular prion $\left(\mathrm{PrP}^{\mathrm{C}}\right)$ and the $2 \mathrm{P}$ domain $\mathrm{K}^{+}$channel TREK1 protein, Biochem. Biophys. Res. Commun. (2006) 346:108-115.

[3] Baron G.S., Wehrly K., Dorward D.W., Chesebro B., Caughey B., Conversion of raft associated prion protein to the protease-resistant state requires insertion of PrP-res ( $\mathrm{PrP}^{\mathrm{Sc}}$ ) into contiguous membranes, EMBO J. (2002) 21:1031-1040.

[4] Baskakov I.V., Legname G., Baldwin M.A., Prusiner S.B., Cohen F.E., Pathway complexity of prion protein assembly into amyloid, J. Biol. Chem. (2002) 277:21140-21148.

[5] Bate C., Salmona M., Diomede L., Williams A., Squalestatin cures prion-infected neurons and protects against prion neurotoxicity, J. Biol. Chem. (2004) 279:14983-14990.

[6] Baumann M.H., Kallijärvi J., Lankinen H., Soto C., Haltia M., Apolipoprotein E includes a binding site which is recognized by several amyloidogenic polypeptides, Biochem. J. (2000) 349:77-84.

[7] Beck K.E., Kay J.G., Braun J.E., Rdj2, a J protein family member, interacts with cellular prion $\mathrm{PrP}^{\mathrm{C}}$, Biochem. Biophys. Res. Commun. (2006) 346:866871. 
[8] Bocharova O.V., Breydo L., Parfenov A.S., Salnikov V.V., Baskakov I.V., In vitro conversion of full-length Mammalian prion protein produces amyloid form with physical properties of $\mathrm{PrP}^{\mathrm{Sc}}$, J. Mol. Biol. (2005) 346:645-659.

[9] Borchelt D.R., Scott M., Taraboulos A., Stahl N., Prusiner S.B., Scrapie and cellular prion proteins differ in their kinetics of synthesis and topology in cultured cells, J. Cell Biol. (1990) 110:743-752.

[10] Bossers A., de Vries R., Smits M.A., Susceptibility of sheep for scrapie as assessed by in vitro conversion of nine naturally occurring variants of PrP, J. Virol. (2000) 74:1407-1414.

[11] Brown D.R., Schmidt B., Kretzschmar H.A., Prion protein fragment interacts with PrP-deficient cells, J. Neurosci. Res. (1998) 52:260-267.

[12] Campana V., Sarnataro D., Fasano C., Casanova P., Paladino S., Zurzolo C., Detergent-resistant membrane domains but not the proteasome are involved in the misfolding of a PrP mutant retained in the endoplasmic reticulum, J. Cell. Sci. (2006) 119:433-442.

[13] Castilla J., Saá P., Hetz C., Soto C., In vitro generation of infectious scrapie prions, Cell (2005) 121:195-206

[14] Caughey B., Race R.E., Vogel M., Buchmeier M.J., Chesebro B., In vitro expression in eukaryotic cells of a prion protein gene cloned from scrapieinfected mouse brain, Proc. Natl. Acad. Sci. USA (1988) 85:4657-4661.

[15] Caughey B., Race R.E., Ernst D., Buchmeier M.J., Chesebro B., Prion protein biosynthesis in scrapieinfected and uninfected neuroblastoma cells, J. Virol. (1989) 63:175-181

[16] Caughey B., Lansbury P.T., Protofibrils, pores, fibrils, and neurodegeneration: separating the responsible protein aggregates from the innocent bystanders, Annu. Rev. Neurosci. (2003) 26:267-298.

[17] Chabry J., Ratsimanohatra C., Sponne I., Elena P.P., Vincent J.P., Pillot T., In vivo and in vitro neurotoxicity of the human prion protein (PrP) fragment P118-135 independently of PrP expression, J. Neurosci. (2003) 23:462-469.

[18] Chernoff Y.O., Stress and prions: lessons from the yeast model, FEBS Lett. (2007) 581:3695-3701.

[19] Chesebro B., Trifilo M., Race R., Meade-White K., Teng C., LaCasse R., et al., Anchorless prion protein results in infectious amyloid disease without clinical scrapie, Science (2005) 308:1435-1439.

[20] Chich J.F., Schaeffer B., Bouin A.P., Mouthon F., Labas V., Larramendy C., et al., Prion infectionimpaired functional blocks identified by proteomics enlighten the targets and the curing pathways of an anti-prion drug, Biochim. Biophys. Acta (2007) 1774:154-167.
[21] Chien P., Weissman J.S., DePace A.H., Emerging principles of conformation-based prion inheritance, Annu. Rev. Biochem. (2004) 73:617-656.

[22] Coitinho A.S., Lopes M.H., Hajj G.N., Rossato J.I., Freitas A.R., Castro C.C., et al., Short-term memory formation and long-term memory consolidation are enhanced by cellular prion association to stressinducible protein 1, Neurobiol. Dis. (2007) 26:282290.

[23] Collinge J., Clarke A.R., A general model of prion strains and their pathogenicity, Science (2007) 318:930-936.

[24] Critchley P., Kazlauskaite J., Eason R., Pinheiro T.J., Binding of prion proteins to lipid membranes, Biochem. Biophys. Res. Commun. (2004) 313:559567.

[25] Cunningham C., Deacon R., Wells H., Boche D., Waters S., Diniz C.P., et al., Synaptic changes characterize early behavioural signs in the ME7 model of murine prion disease, Eur. J. Neurosci. (2003) 17:2147-2155.

[26] De Simone A., Dodson G.G., Fraternali F., Zagari A., Water molecules as structural determinants among prions of low sequence identity, FEBS Lett. (2006) 580:2488-2494.

[27] DebBurman S.K., Raymond G.J., Caughey B., Lindquist S., Chaperone-supervised conversion of prion protein to its protease-resistant form, Proc. Natl. Acad. Sci. USA (1997) 94:13938-13943.

[28] Dima R.I., Thirumalai D., Probing the instabilities in the dynamics of helical fragments from mouse $\operatorname{PrP}^{\mathrm{C}}$, Proc. Natl. Acad. Sci. USA (2004) 101:15335-15340.

[29] Donne D.G., Viles J.H., Groth D., Mehlhorn I., James T.L., Cohen F.E., et al., Structure of the recombinant full-length hamster prion protein $\operatorname{PrP}(29-231)$ : the $\mathrm{N}$ terminus is highly flexible., Proc. Natl. Acad. Sci. USA (1997) 94:13452-13457.

[30] Eberl H., Tittmann P., Glockshuber R., Characterization of recombinant, membrane-attached full-length prion protein, J. Biol. Chem. (2004) 279:25058-25065.

[31] Edenhofer F., Rieger R., Famulok M., Wendler W., Weiss S., Winnacker E.L., Prion protein $\operatorname{PrP}^{\mathrm{C}}$ interacts with molecular chaperones of the Hsp60 family, J. Virol. (1996) 70:4724-4728.

[32] Eghiaian F., Grosclaude J., Lesceu S., Debey P., Doublet B., Tréguer E., et al., Insight into the $\operatorname{PrP}^{\mathrm{C}}$ $\rightarrow \mathrm{PrP}^{\mathrm{Sc}}$ conversion from the structures of antibodybound ovine prion scrapie-susceptibility variants, Proc. Natl. Acad. Sci. USA (2004) 101:10254-10259.

[33] Eghiaian F., Daubenfeld T., Quenet Y., van Audenhaege M., Bouin A.P., van der Rest G., et al., Diversity in prion protein oligomerization pathways 
results from domain expansion as revealed by hydrogen/deuterium exchange and disulfide linkage, Proc. Natl. Acad. Sci. USA (2007) 104:7414-7419.

[34] Enari M., Flechsig E., Weissmann C., Scrapie prion protein accumulation by scrapie-infected neuroblastoma cells abrogated by exposure to a prion protein antibody, Proc. Natl. Acad. Sci. USA (2001) 98:9295-9299.

[35] Féraudet C., Morel N., Simon S., Volland H., Frobert Y., Créminon C., et al., Screening of 145 antiPrP monoclonal antibodies for their capacity to inhibit PrPSc replication in infected cells, J. Biol. Chem. (2005) 280:11247-11258.

[36] Fischer M., Rülicke T., Raeber A.J., Sailer A., Moser M., Oesch B., et al., Prion portein (PrP) with amino-proximal deletions restoring susceptibility of PrP konckout mice to scrapie, EMBO J. (1996) 15:1255-1264.

[37] Fischer M.B., Roeckl C., Parizek P., Schwarz H.P., Aguzzi A., Binding of disease-associated prion protein to plasminogen, Nature (2000) 408:479-483.

[38] Gabizon R., Meiner Z., Halimi M., Ben-Sasson S.A., Heparin-like molecules bind differentially to prion-proteins and change their intracellular metabolic fate, J. Cell. Physiol. (1993) 157:319-325.

[39] Gajdusek D.C., Transmissible and nontransmissible amyloidoses: autocatalytic post-translational conversion of host precursor proteins to $\beta$-pleated sheet configurations, J. Neuroimmunol. (1988) 20:95-110.

[40] Giese A., Groschup M.H., Hess B., Kretzschmar H.A., Neuronal cell death in scrapie-infected mice is due to apoptosis, Brain Pathol. (1995) 5:213-221.

[41] Gossert A.D., Bonjour S., Lysek D.A., Fiorito F., Wüthrich K., Prion protein NMR structures of elk and of mouse/elk hybrids, Proc. Natl. Acad. Sci. USA (2005) 102:646-650.

[42] Graner E., Mercadante A.F., Zanata S.M., Forlenza O.V., Cabral A.L., Veiga S.S., et al., Cellular prion protein binds laminin and mediates neuritogenesis, Brain Res. Mol. Brain Res. (2000) 76:85-92.

[43] Haire L.F., Whyte S.M., Vasisht N., Gill A.C., Verma C., Dodson E.J., et al., The crystal structure of the globular domain of sheep prion protein, J. Mol. Biol. (2004) 336:1175-1183.

[44] Hajj G.N., Lopes M.H., Mercadante A.F., Veiga S.S., da Silveira R.B., Santos T.G., et al., Cellular prion protein interaction with vitronectin supports axonal growth and is compensated by integrins, J. Cell Sci. (2007) 120:1915-1926.

[45] Heppner F.L., Musahl C., Arrighi I., Klein M.A., Rülicke T., Oesch B., et al., Prevention of scrapie pathogenesis by transgenic expression of anti-prion protein antibodies, Science (2001) 294:178-182.
[46] Hornemann S., Schorn C., Wüthrich K., NMR structure of the bovine prion protein isolated from healthy calf brains, EMBO Rep. (2004) 5:1159-1164.

[47] Hornshaw M.P., McDermott J.R., Candy J.M., Lakey J.H., Copper binding to the N-terminal tandem repeat region of mammalian and avian prion protein: structural studies using synthetic peptides, Biochem. Biophys. Res. Commun. (1995) 214:993-999.

[48] Hundt C., Peyrin J.M., Haïk S., Gauczynski S., Leucht C., Rieger R., et al., Identification of interaction domains of the prion protein with its $37-\mathrm{kDa} / 67-\mathrm{kDa}$ laminin receptor, EMBO J. (2001) 20:5876-5886.

[49] Hunter N., Goldmann W., Benson G., Foster J.D., Hope J., Swaledale sheep affected by natural scrapie differ significantly in $\mathrm{PrP}$ genotype frequencies from healthy sheep and those selected for reduced incidence of scrapie, J. Gen. Virol. (1993) 74:1025-1031.

[50] Jansen K., Schäfer O., Birkmann E., Post K., Serban H., Prusiner S.B., et al., Structural intermediates in the putative pathway from the cellular prion protein to the pathogenic form, Biol. Chem. (2001) 382:683-691.

[51] Jarrett J.T., Lansbury P.T. Jr., Seeding "onedimensional crystallization" of amyloid: a pathogenic mechanism in Alzheimer's disease and scrapie?, Cell (1993) 73:1055-1058.

[52] Jeffrey M., Halliday W.G., Bell J., Johnston A.R., MacLeod N.K., Ingham C., et al., Synapse loss associated with abnormal PrP precedes neuronal degeneration in the scrapie-infected murine hippocampus, Neuropathol. Appl. Neurobiol. (2000) 26:41-54.

[53] Jones E.M., Surewicz W.K., Fibril conformation as the basis of species- and strain-dependent seeding specificity of mammalian prion amyloids, Cell (2005) 121:63-72.

[54] Kaneko K., Zulianello L., Scott M., Cooper C.M., Wallace A.C., James T.L., et al., Evidence for protein $\mathrm{X}$ binding to a discontinuous epitope on the cellular prion protein during scrapie prion propagation, Proc. Natl. Acad. Sci. USA (1997) 94:10069-10074.

[55] Kazlauskaite J., Sanghera N., Sylvester I., Vénien-Bryan C., Pinheiro T.J., Structural changes of the prion protein in lipid membranes leading to aggregation and fibrillization, Biochemistry (2003) 42:3295-3304.

[56] Kazlauskaite J., Young A., Gardner C.E., Macpherson J.V., Vénien-Bryan C., Pinheiro T.J., An unusual soluble $\beta$-turn-rich conformation of prion is involved in fibril formation and toxic to neuronal cells, Biochem. Biophys. Res. Commun. (2005) 328:292-305.

[57] Kourie J.I., Culverson A., Prion peptide fragment PrP(106-126) forms distinct cation channel types, J. Neurosci. Res. (2000) 62:120-133. 
[58] Kurschner C., Morgan J.I., The cellular prion protein $(\mathrm{PrP})$ selectively binds to $\mathrm{Bcl}-2$ in the yeast two-hybrid system, Brain Res. Mol. Brain Res. (1995) 30:165-168.

[59] Lee K.S., Caughey B., A simplified recipe for prions, Proc. Natl. Acad. Sci. USA (2007) 104:95519552.

[60] Legname G., Baskakov I.V., Nguyen H.O., Riesner D., Cohen F.E., DeArmond S.J., et al., Synthetic mammalian prions, Science (2004) 305:673676.

[61] Lopes M.H., Hajj G.N., Muras A.G., Mancini G.L., Castro R.M., Ribeiro K.C., et al., Interaction of cellular prion and stress-inducible protein 1 promotes neuritogenesis and neuroprotection by distinct signaling pathways, J. Neurosci. (2005) 25:11330-11339.

[62] López Garcia F., Zahn R., Riek R., Wüthrich K., NMR structure of the bovine prion protein, Proc. Natl. Acad. Sci. USA (2000) 97:8334-8339.

[63] Lu X., Wintrode P.L., Surewicz W.K., $\beta$-sheet core of human prion protein amyloid fibrils as determined by hydrogen/deuterium exchange, Proc. Natl. Acad. Sci. USA (2007) 104:1510-1515.

[64] Lysek D.A., Schorn C., Nivon L.G., Esteve-Moya V., Christen B., Calzolai L., et al., Prion protein NMR structures of cats, dogs, pigs, and sheep, Proc. Natl. Acad. Sci. USA (2005) 102:640-645.

[65] Ma J., Lindquist S., Conversion of PrP to a selfperpetuating $\mathrm{PrP}^{\mathrm{Sc}}$-like conformation in the cytosol, Science (2002) 298:1785-1788.

[66] Ma J., Wollmann R., Lindquist S., Neurotoxicity and neurodegeneration when PrP accumulates in the cytosol, Science (2002) 298:1781-1785.

[67] Maissen M., Roeckl C., Glatzel M., Goldmann W., Aguzzi A., Plasminogen binds to diseaseassociated prion protein of multiple species, Lancet (2001) 357:2026-2028.

[68] Makarava N., Baskakov I.V., The same primary structure of the prion protein yields two distinct selfpropagating states, J. Biol. Chem. (2008) 283:1598815996.

[69] Martins S.M., Chapeaurouge A., Ferreira S.T., Folding intermediates of the prion protein stabilized by hydrostatic pressure and low temperature, J. Biol. Chem. (2003) 278:50449-50455.

[70] Martins V.R., Graner E., Garcia-Abreu J., de Souza S.J., Mercadante A.F., Veiga S.S., et al., Complementary hydropathy identifies a cellular prion protein receptor, Nat. Med. (1997) 3:1376-1382.

[71] Martins V.R., A receptor for infectious and cellular prion protein, Braz. J. Med. Biol. Res. (1999) 32:853-859.
[72] Mattei V., Garofalo T., Misasi R., Gizzi C., Mascellino M.T., Dolo V., et al., Association of cellular prion protein with gangliosides in plasma membrane microdomains of neural and lymphocytic cells, Neurochem. Res. (2002) 27:743-749.

[73] May B.C., Govaerts C., Prusiner S.B., Cohen F.E., Prions: so many fibers, so little infectivity, Trends Biochem. Sci. (2004) 29:162-165.

[74] Moore R.A., Vorberg I., Priola S.A., Species barriers in prion diseases - brief review, Arch. Virol. Suppl. (2005) 187-202.

[75] Morillas M., Swietnicki W., Gambetti P., Surewicz W.K., Membrane environment alters the conformational structure of the recombinant human prion protein, J. Biol. Chem. (1999) 274:3685936865 .

[76] Morillas M., Vanik D.L., Surewicz W.K., On the mechanism of $\alpha$-helix to $\beta$-sheet transition in the recombinant prion protein, Biochemistry (2001) 40:6982-6987.

[77] Morot-Gaudry-Talarmain Y., Rezaei H., Guermonprez L., Treguer E., Grosclaude J., Selective prion protein binding to synaptic components is modulated by oxidative and nitrosative changes induced by copper(II) and peroxynitrite in cholinergic synaptosomes, unveiling a role for calcineurin B and thioredoxin, J. Neurochem. (2003) 87:1456-1470.

[78] Morrissey M.P., Shakhnovich E.I., Evidence for the role of $\operatorname{PrP}^{\mathrm{C}}$ helix 1 in the hydrophilic seeding of prion aggregates, Proc. Natl. Acad. Sci. USA (1999) 96:11293-11298.

[79] Mouillet-Richard S., Ermonval M., Chebassier C., Laplanche J.L., Lehmann S., Launay J.M., Kellermann O., Signal transduction through prion protein, Science (2000) 289:1925-1928.

[80] Nandi P.K., Interaction of prion peptide HuPrP106-126 with nucleic acid, Arch. Virol. (1997) 142:2537-2545.

[81] Nandi P.K., Sizaret P.Y., Murine recombinant prion protein induces ordered aggregation of linear nucleic acids to condensed globular structures, Arch. Virol. (2001) 146:327-345.

[82] Naslavsky N., Shmeeda H., Friedlander G., Yanai A., Futerman A.H., Barenholz Y., et al., Sphingolipid depletion increases formation of the scrapie prion protein in neuroblastoma cells infected with prions, J. Biol. Chem. (1999) 274:20763-20771.

[83] Novitskaya V., Bocharova O.V., Bronstein I., Baskakov I.V., Amyloid fibrils of mammalian prion protein are highly toxic to cultured cells and primary neurons, J. Biol. Chem. (2006) 281:13828-13836.

[84] Novitskaya V., Makarava N., Sylvester I., Bronstein I.B., Baskakov I.V., Amyloid fibrils of mammalian prion protein induce axonal degeneration in 
NTERA2-derived terminally differentiated neurons, J. Neurochem. (2007) 102:398-407.

[85] Oboznaya M.B., Gilch S., Titova M.A., Koroev D.O., Volkova T.D., Volpina O.M., et al., Antibodies to a nonconjugated prion protein peptide 95-123 interfere with $\mathrm{PrP}^{\mathrm{Sc}}$ propagation in prion-infected cells, Cell. Mol. Neurobiol. (2007) 27:271-284.

[86] Oesch B., Westaway D., Wälchli M., McKinley M.P., Kent S.B., Aebersold R., et al., A cellular gene encodes scrapie PrP 27-30 protein, Cell (1985) 40:735-746.

[87] Oesch B., Teplow D.B., Stahl N., Serban D., Hood L.E., Prusiner S.B., Identification of cellular proteins binding to the scrapie prion protein, Biochemistry (1990) 29:5848-5855.

[88] Oosawa F., Asakura S., Thermodynamics of the polymerization of protein, Academic Press, New York, USA, 1975, p. 223.

[89] Owen J.P., Rees H.C., Maddison B.C., Terry L.A., Thorne L., Jackman R., et al., Molecular profiling of ovine prion diseases by using thermolysin-resistant $\mathrm{PrP}^{\mathrm{Sc}}$ and endogenous $\mathrm{C} 2 \mathrm{PrP}$ fragments, J. Virol. (2007) 81:10532-10539.

[90] Pan K.M., Baldwin M., Nguyen J., Gasset M., Serban A., Groth D., et al., Conversion of $\alpha$-helices into $\beta$-sheets features in the formation of the scrapie prion proteins, Proc. Natl. Acad. Sci. USA (1993) 90:10962-10966.

[91] Parizek P., Roeckl C., Weber J., Flechsig E., Aguzzi A., Raeber A.J., Similar turnover and shedding of the cellular prion protein in primary lymphoid and neuronal cells, J. Biol. Chem. (2001) 276:4462744632.

[92] Peretz D., Williamson R.A., Kaneko K., Vergara J., Leclerc E., Schmitt-Ulms G., et al., Antibodies inhibit prion propagation and clear cell cultures of prion infectivity, Nature (2001) 412:739-743.

[93] Peretz D., Williamson R.A., Legname G., Matsunaga Y., Vergara J., Burton D.R., et al., A change in the conformation of prions accompanies the emergence of a new prion strain, Neuron (2002) 34:921932 .

[94] Pillot T., Drouet B., Pinçon-Raymond M., Vandekerckhove J., Rosseneu M., Chambaz J., A nonfibrillar form of the fusogenic prion protein fragment (118-135) induces apoptotic cell death in rat cortical neurons, J. Neurochem. (2000) 75:2298-2308.

[95] Prusiner S.B., Novel proteinaceous infectious particles cause scrapie, Science (1982) 216:136-144.

[96] Prusiner S.B., Prions, Proc. Natl. Acad. Sci. USA (1998) 95:13363-13383.

[97] Rambold A.S., Miesbauer M., Rapaport D., Bartke T., Baier M., Winklhofer K.F., et al.,
Association of $\mathrm{Bcl}-2$ with misfolded prion protein is linked to the toxic potential of cytosolic PrP, Mol. Biol. Cell (2006) 17:3356-3368.

[98] Rezaei H., Choiset Y., Eghiaian F., Treguer E., Mentre P., Debey P., et al., Amyloidogenic unfolding intermediates differentiate sheep prion protein variants, J. Mol. Biol. (2002) 322:799-814.

[99] Rezaei H., Eghiaian F., Perez J., Doublet B., Choiset Y., Haertle T., et al., Sequential generation of two structurally distinct ovine prion protein soluble oligomers displaying different biochemical reactivities, J. Mol. Biol. (2005) 347:665-679.

[100] Rieger R., Edenhofer F., Lasmézas C.I., Weiss $\mathrm{S}$., The human $37-\mathrm{kDa}$ laminin receptor precursor interacts with the prion protein in eukaryotic cells, Nat. Med. (1997) 3:1383-1388.

[101] Riek R., Hornemann S., Wider G., Billeter M., Glockshuber R., Wüthrich K., NMR structure of the mouse prion protein domain PrP (121-321), Nature (1996) 382:180-182.

[102] Rogers M., Yehiely F., Scott M., Prusiner S.B., Conversion of truncated and elongated prion proteins into the scrapie isoform in cultured cells, Proc. Natl. Acad. Sci. USA (1993) 90:3182-3186.

[103] Rudd P.M., Endo T., Colominas C., Groth D., Wheeler S.F., Harvey D.J., et al., Glycosylation differences between the normal and pathogenic prion protein isoforms, Proc. Natl. Acad. Sci. USA (1999) 96:13044-13049.

[104] Rybner C., Finel-Szermanski S., Felin M., Sahraoui T., Rousseau C., Fournier J.G., et al., The cellular prion protein: a new partner of the lectin CBP70 in the nucleus of NB4 human promyelocytic leukemia cells, J. Cell. Biochem. (2002) 84:408-419.

[105] Ryou C., Prusiner S.B., Legname G., Cooperative binding of dominant-negative prion protein to kringle domains, J. Mol. Biol. (2003) 329:323-333.

[106] Safar J., Ceroni M., Gajdusek D.C., Gibbs C.J. Jr., Differences in the membrane interaction of scrapie amyloid precursor proteins in normal and scrapieor Creutzfeldt-Jakob disease-infected brains, J. Infect. Dis. (1991) 163:488-494.

[107] Sanghera N., Pinheiro T.J., Binding of prion protein to lipid membranes and implications for prion conversion, J. Mol. Biol. (2002) 315:1241-1256.

[108] Schirmer E.C., Lindquist S., Interactions of the chaperone Hsp104 with yeast Sup35 and mammalian PrP, Proc. Natl. Acad. Sci. USA (1997) 94:1393213937.

[109] Schmitt-Ulms G., Legname G., Baldwin M.A., Ball H.L., Bradon N., Bosque P.J., et al., Binding of neural cell adhesion molecules (N-CAMs) to the cellular prion protein, J. Mol. Biol. (2001) 314:1209-1225. 
[110] Shmerling D., Hegyi I., Fischer M., Blättler T., Brandner S., Götz J., et al., Expression of aminoterminally truncated PrP in the mouse leading to ataxia and specific cerebellar lesions, Cell (1998) 93:203214.

[111] Shyng S.L., Lehmann S., Moulder K.L., Harris D.A., Sulfated glycans stimulate endocytosis of the cellular isoform of the prion protein, $\mathrm{PrP}^{\mathrm{C}}$, in cultured cells, J. Biol. Chem. (1995) 270:30221-30229.

[112] Shyu W.C., Harn H.J., Saeki K., Kubosaki A., Matsumoto Y., Onodera T., et al., Molecular modulation of expression of prion protein by heat shock, Mol. Neurobiol. (2002) 26:1-12.

[113] Silveira J.R., Raymond G.J., Hughson A.G., Race R.E., Sim V.L., Hayes S.F., et al., The most infectious prion protein particles, Nature (2005) 437:257261.

[114] Simoneau S., Rezaei H., Salès N., Kaiser-Schulz G., Lefebvre-Roque M., Vidal C., et al., In vitro and in vivo neurotoxicity of prion protein oligomers, PLoS Pathog. (2007) 3:e125.

[115] Spielhaupter C., Schätzl H.M., PrP ${ }^{C}$ directly interacts with proteins involved in signaling pathways, J. Biol. Chem. (2001) 276:44604-44612.

[116] Stahl N., Borchelt D.R., Hsiao K., Prusiner S.B., Scrapie prion protein contains a phosphatidylinositol glycolipid, Cell (1987) 51:229-240.

[117] Stahl N., Borchelt D.R., Prusiner S.B., Differential release of cellular and scrapie prion proteins from cellular membranes by phosphatidylinositol-specific phospholipase C, Biochemistry (1990) 29:5405-5412.

[118] Stahl N., Prusiner S.B., Prions and prion proteins, FASEB J. (1991) 5:2799-2807.

[119] Stöckel J., Safar J., Wallace A.C., Cohen F.E., Prusiner S.B., Prion protein selectively binds copper(II) ions, Biochemistry (1998) 37:7185-7193.

[120] Sun Y., Makarava N., Lee C.I., Laksanalamai P., Robb F.T., Baskakov I.V., Conformational stability of PrP amyloid fibrils controls their smallest possible fragment size, J. Mol. Biol. (2008) 376:1155-1167.
[121] Sunyach C., Jen A., Deng J., Fitzgerald K.T., Frobert Y., Grassi J., et al., The mechanism of internalization of glycosylphosphatidylinositol-anchored prion protein, EMBO J. (2003) 22:3591-3601.

[122] Swietnicki W., Morillas M., Chen S.G., Gambetti P., Surewicz W.K., Aggregation and fibrillization of the recombinant human prion protein huPrP90-231, Biochemistry (2000) 39:424-431.

[123] Taraboulos A., Scott M., Semenov A., Avrahami D., Laszlo L., Prusiner S.B., Cholesterol depletion and modification of $\mathrm{COOH}$-terminal targeting sequence of the prion protein inhibit formation of the scrapie isoform, J. Cell Biol. (1995) 129:121-132.

[124] Tatzelt J., Zuo J., Voellmy R., Scott M., Hartl U., Prusiner S.B., et al., Scrapie prions selectively modify the stress response in neuroblastoma cells, Proc. Natl. Acad. Sci. USA (1995) 92:2944-2948.

[125] Telling G.C., Scott M., Mastriannni J., Gabizon R., Torchia M., Cohen F.E., et al., Prion propagation in mice expressing human and chimeric PrP transgenes implicates the interaction of cellular PrP with another protein., Cell (1995) 83:79-90.

[126] Telling G.C., Parchi P., DeArmond S.J., Cortelli P., Montagna P., Gabizon R., et al., Evidence for the conformation of the pathologic isoform of the prion protein enciphering and propagating prion diversity, Science (1996) 274:2079-2082.

[127] Toni M., Spisni E., Griffoni C., Santi S., Riccio M., Lenaz P., et al., Cellular prion protein and caveolin1 interaction in a neuronal cell line precedes fyn/erk 1/2 signal transduction, J. Biomed. Biotechnol. (2006) 2006:69469.

[128] Weiss S., Proske D., Neumann M., Groschup M.H., Kretzschmar H.A., Famulok M., et al., RNA aptamers specifically interact with the prion protein PrP, J. Virol. (1997) 71:8790-8797.

[129] Yehiely F., Bamborough P., Da Costa M., Perry B.J., Thinakaran G., Cohen F.E., et al., Identification of candidate proteins binding to prion protein, Neurobiol. Dis. (1997) 3:339-355. 